\title{
Granulosain I, a Cysteine Protease Isolated from Ripe Fruits of Solanum granuloso-leprosum (Solanaceae)
}

\author{
Diego Vallés · Mariela Bruno · Laura M. I. López · \\ Néstor O. Caffini · Ana María B. Cantera
}

Published online: 14 May 2008

(C) The Author(s) 2008

\begin{abstract}
A new cysteine peptidase (Granulosain I) was isolated from ripe fruits of Solanum granuloso-leprosum Dunal (Solanaceae) by means of precipitation with organic solvent and cation exchange chromatography. The enzyme showed a single band by SDS-PAGE, its molecular mass was 24,746 Da (MALDI-TOF/MS) and its isoelectric point was higher than 9.3. It showed maximum activity (more than 90\%) in the $\mathrm{pH}$ range 7-8.6. Granulosain I was completely inhibited by E-64 and activated by the addition of cysteine or 2-mercaptoethanol, confirming its cysteinic nature. The kinetic studies carried out with PFLNA as substrate, showed an affinity $(\mathrm{Km} 0.6 \mathrm{mM})$ slightly lower than those of other known plant cysteine proteases (papain and bromelain). The N-terminal sequence of granulosain I (DRLPASVDWRGKGVLVLVKNQGQC) exhibited a close homology with other cysteine proteases belonging to the C1A family.
\end{abstract}

Keywords Solanum granuloso-leprosum - Solanaceae · Cysteine protease $\cdot$ Plant peptidases

D. Vallés · A. M. B. Cantera

Laboratorio de Enzimas Hidrolíticas, Facultad de Ciencias,

Universidad de la República (UdelaR), Montevideo, Uruguay

M. Bruno · L. M. I. López · N. O. Caffini

Laboratorio de Investigación de Proteínas Vegetales

(LIPROVE), Departamento de Ciencias Biológicas, Facultad de

Ciencias Exactas, Universidad Nacional de La Plata, La Plata,

Argentina

A. M. B. Cantera $(\square)$

Cátedra de Bioquímica, Facultad de Química, Universidad de la República (UdelaR), Montevideo, Uruguay

e-mail: acantera@fq.edu.uy

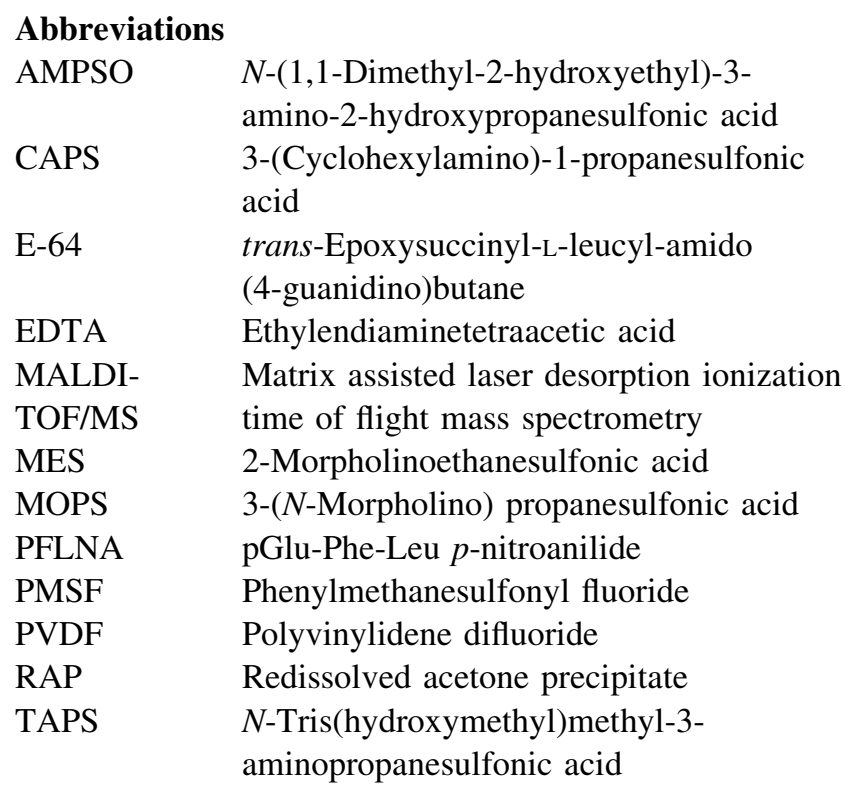

\section{Introduction}

The cysteine proteases of clan CA, family $\mathrm{C} 1$ (the papain family), are a group of enzymes identified in bacteria, yeast, animals, and plants, which play an important role in intracellular protein degradation [1]. These enzymes share not only their general architecture but also the microarrangement of the catalytic residues Cys 25, His 159 and Asn 175 (according to the papain numbering). The ionized state of the nucleophilic cysteine residue in the active site is independent of substrate binding, making these and other cysteine proteases active a priori [2].

The family of papain-type proteinases is the most thoroughly investigated among all the cysteine proteinases. Papain is characterized by a two-domain structure with the 
active site between the domains. These enzymes are usually synthesized as inactive or less active precursors. Activation takes place by limited intra- or intermolecular proteolysis [3]. To date, the amino acid sequences of more than 50 papain-like and 15 legumain-like plant proteinases have been established [4]. They are stored in the vacuole or the lysosome, or are externally secreted. Among the cysteine proteases, the $\mathrm{H}$ and $\mathrm{L}$ cathepsins have been widely studied in mammals and, more recently, in plants [5].

Plant proteinases of this class are mainly used to mobilize storage proteins in seeds. Protein bodies of seeds contain both storage proteins and protease precursors. The latter become activated after germination and start degradation of the stored proteins [6]. The activities of cysteine proteinases respond dramatically to different internal and external stimuli and in some cases they rise to $90 \%$ of total proteolytic activity. They are involved in protein maturation, degradation and protein rebuilt in response to different external stimuli and they also play a house-keeping function to remove abnormal misfolded proteins [7].

Some of these enzymes have medical significance because they are resorbed in the gut as active enzymes and may elicit an immune response $[8,9]$.

A number of these proteinases have an essential role in processes used by the modern food and feed industry, to produce a wide range of products for human and animal consumption. They have been exploited commercially in the food industry for meat tenderizing (partially separating connective tissues), brewing (to solubilize grain proteins and stabilize beer), and cookie baking (to improve crispness), as well as the production of protein hydrolysates [10]. Protein hydrolysates are currently employed to produce many foods in which enzymes can replace potentially carcinogenic or otherwise harmful chemicals. They also have applications in tanning, leather and textile industries, to remove hair, wool, and to soften skins [11].

Our groups are dedicated to the search for new sources of plant proteolytic enzymes, their purification and biochemical characterization. Some of us [12, 13] have studied stabilization by adsorption and are exploring potential biotechnological applications. Here we report the characterization of Granulosain I, the major protease purified from crude extracts of ripe fruits of Solanum granuloso-leprosum (Solanaceae).

In contrast to the rest of this family, S. granuloso-leprosum is a tree growing 4-6 m tall, whereas most other members are plants or shrubs, 1 or $2 \mathrm{~m}$ tall. Another distinguishing characteristic with the rest of this family, is that the $S$. granuloso-leprosum is an arboreal constitution (being able to reach 4-6 m high) whereas the majority of the members have constitution type kills or shrub (1 or $2 \mathrm{~m}$ high).
The Solanaceae are also the third most important plant taxon economically and the most valuable in terms of vegetable crops, and are the most variable of crops species in terms of agricultural utility, as it includes the tuberbearing potato, a number of fruit-bearing vegetables (tomato, eggplant, peppers), ornamental plants (petunias, Nicotiana), plants with edible leaves (Solanum aethiopicum, S. macrocarpon) and medicinal plants (e.g. Datura, Capsicum) [14].

\section{Material and Methods}

\subsection{Chemicals}

$\mathrm{AMPSO}^{4}$, CAPS, casein, Coomasie Brillant Blue R-250 and G-250, cysteine, E-64, EDTA, MOPS, PFLNA, PMSF, PVDF membrane, TAPS, Tris base and glycine were purchased from Sigma Chemical Company (St. Louis, MO, USA). Acrylamide, bisacrylamide, and low-range molecular weight standards were obtained from Bio-Rad (Hercules, CA, USA) CM-Sepharose Fast Flow and Pharmalyte 3-10 were purchased from Pharmacia (Biotech. Uppsala, Sweden). All other chemical were obtained from commercial sources and were of the highest available purity.

\subsection{Plant Material}

Ripe fresh fruits from S. granuloso-leprosum Dunal $[$ syn $=S$. verbascifolium var. auriculatum (Ait.) O.K.], Solanaceae, were collected in January from wild trees that grow in Montevideo city. The plant (a shrub or small tree) grows in northeastern Argentina, Uruguay and Brazil and the fruits are orange berries, about $1-2 \mathrm{~cm}$ long.

\subsection{Crude Extract Preparation}

A crude extract was prepared by grinding fresh mature fruits, previously washed and dried, in a mortar. Homogenates were filtered through a piece of gauze folded in two to remove plant debris, and then centrifuged for $15 \mathrm{~min}$ at $6,654 \mathrm{~g}$. The supernatant (crude extract) was stored at $-20{ }^{\circ} \mathrm{C}$ for further analysis.

\subsection{Preliminary Purification of Crude Extract}

The crude extract was treated with four volumes of cold $\left(-20{ }^{\circ} \mathrm{C}\right)$ acetone with gentle agitation and left to settle for $20 \mathrm{~min}$ before centrifugation at $6,654 \mathrm{~g}$ for $30 \mathrm{~min}$. The final acetone precipitate (RAP) was redissolved with one volume of $50 \mathrm{mM}$ buffer Tris- $\mathrm{HCl} \mathrm{pH} 7.5$ [15]. 


\subsection{Protein Content Determination}

Proteins present in the crude extract and in the partial purified fractions were measured according to Bradford's method [16] using bovine seroalbumin as the standard. The protein content of chromatographic fractions was estimated by measurement of absorbance at $280 \mathrm{~nm}$.

\subsection{Proteolytic Activity Determination}

Casein was the substrate used in most cases. The reaction mixture contained $0.1 \mathrm{~mL}$ of crude extract and $1.1 \mathrm{~mL}$ of $1 \%$ casein in a $0.1 \mathrm{M}$ Tris- $\mathrm{HCl}$ buffer $(\mathrm{pH} 7.5)$ with $15 \mathrm{mM}$ cysteine (final concentration). The reaction was carried out at $37{ }^{\circ} \mathrm{C}$ and stopped 20 min later by adding $1.8 \mathrm{~mL}$ of $5 \%(\mathrm{w} / \mathrm{v})$ trichloroacetic acid (TCA). Each test tube was centrifuged at $6,000 \mathrm{~g}$ for $30 \mathrm{~min}$ and the absorbance of the supernatant was measured at $280 \mathrm{~nm}$. One caseinolytic unit (Ucas) was defined as the amount of protease that produces an increment of one absorbance unit per minute in the assay conditions [17].

Azocasein was the substrate used in titration assays with E64 . The reaction mixture containing $340 \mu \mathrm{L}$ of an appropriate dilution of the enzyme preparation, $340 \mu \mathrm{L}$ of azocasein solution ( $1 \% \mathrm{w} / \mathrm{v}$ in distiller water) and $340 \mu \mathrm{L}$ of buffer (0.1 M Tris- $\mathrm{HCl}$ buffer, $\mathrm{pH} 7.5$ ) was incubated for $20 \mathrm{~min}$ at $37{ }^{\circ} \mathrm{C}$. The reaction was stopped by adding $340 \mu \mathrm{L}$ of TCA $(10 \% \mathrm{w} / \mathrm{v}$ in distilled water). After centrifuging for $20 \mathrm{~min}$ at $20,600 \mathrm{~g}$, absorbance was measured at $337 \mathrm{~nm}$. In this case, one enzymatic unit (Uazo) was defined as the quantity of enzyme required to increase by one absorbance unit the absorbance value at $337 \mathrm{~nm}$ per minute in the assay conditions [18].

\subsection{Cation-Exchange Chromatography}

The RAP (redissolved acetone precipitate) was purified by cation exchange chromatography on a column (Pharmacia XK 16/40, with AK16 adaptors) packed with CMSepharose Fast Flow, equilibrated and washed with $50 \mathrm{mM}$ Tris-HCl buffer ( $\mathrm{pH}$ 7.5). Chromatography was carried out in FPLC equipment (Pharmacia) by washing with the equilibrating buffer and further elution of the bound material with a linear sodium chloride gradient $(0-0.3 \mathrm{M})$ in the same starting buffer at a flow rate of $2 \mathrm{~mL} / \mathrm{min}$. The protein content of the chromatographic fractions was monitored spectrophotometrically by measuring absorption at $280 \mathrm{~nm}$. The eluted fractions were assayed for caseinolytic activity, and those showing proteolytic activity were pooled and stored at $-20{ }^{\circ} \mathrm{C}$ for further studies.

\subsection{Optimum $\mathrm{pH}$}

Caseinolytic activity was measured at $37{ }^{\circ} \mathrm{C}$ at different $\mathrm{pH}$ values (6-10) using $10 \mathrm{mM}$ sodium salts of the following
"Good" buffers: MES, MOPS, TAPS, AMPSO and CAPS [19].

\subsection{Effect of Activators}

The effect of activity enhancers was determined by measuring the caseinolytic activity in $0.1 \mathrm{M}$ Tris buffer $\mathrm{pH} 7.5$ after preincubating the sample with the activator at $37{ }^{\circ} \mathrm{C}$ for $30 \mathrm{~min}$. The activators assayed were $\beta$-mercaptoethanol and cysteine $(5,10,15,20,30$ and $50 \mathrm{mM}$ final concentration). The activity was compared with the enzyme without the addition of inhibitors or activators.

\subsection{Titration of the Active Site with E-64}

Titration of the active site was performed as described by Salvesen and Nagase [20], with some modifications. The enzyme $(0.6 \mu \mathrm{M})$ was preincubated with the activation buffer $(50 \mathrm{mM}$ Tris- $\mathrm{HCl} \mathrm{pH} 7.5$, containing $15 \mathrm{mM}$ cysteine). Fractions $(0.75 \mu \mathrm{L})$ were incubated with $25 \mu \mathrm{L}$ of different concentrations $(0-2 \mu \mathrm{M})$ of E-64 for $30 \mathrm{~min}$ at $37{ }^{\circ} \mathrm{C}$ and the residual azocaseinolytic activity was measured. Enzyme concentration was established by determining both protein content (Bradford method) and molecular mass value (mass spectrometry).

\subsection{Isoelectric Focusing (IEF) and Zymogram}

Isoelectric focusing (IEF) was carried out in 5\% polyacrylamide gels containing a broad $\mathrm{pH}$ range of ampholytes (Biolyte 3-10, Bio-Rad) in a Mini IEF Cell (Model 111, Bio-Rad). Samples were precipitated with four volumes of cold $\left(-20{ }^{\circ} \mathrm{C}\right)$ acetone and redissolved twice in deionized water. About 1-10 $\mu \mathrm{g}$ of protein was loaded in each case. Focusing was carried out under constant voltage conditions in a stepped procedure: $100 \mathrm{~V}$ for $15 \mathrm{~min}, 200 \mathrm{~V}$ for the following $15 \mathrm{~min}$, and $450 \mathrm{~V}$ for the last $60 \mathrm{~min}$.

One of the gels was fixed and stained with Coomassie Brilliant Blue R-250, while the other, unstained, was put in contact with an agarose gel of the same dimensions preequilibrated with $1 \%$ casein solution for $20 \mathrm{~min}$ at $56{ }^{\circ} \mathrm{C}$, in order to detect bands with proteolytic activity [21]. After incubation, the agarose gel was dehydrated and stained with Coomassie Brilliant Blue R-250.

\subsection{Electrophoresis}

After each purification step, the fraction was tested by SDS-PAGE in $12.5 \%$ polyacrylamide gels [22]. Current was kept constant at $30 \mathrm{~V}$ during stacking and then increased to $90 \mathrm{~V}$ and kept constant for the resolving gel. The protein bands were visualized by staining with Coomassie Brilliant Blue R-250. 


\subsection{Mass Spectrometry}

Purity, and the molecular weight of the contents of chromatographic fractions, were determined by matrix-assisted laser desorption/ionization time of flight mass spectrometry (MALDI-TOF/MS).

MALDI-TOF mass spectra were obtained using a Bruker Daltonics ${ }^{\circledR}$ model Ultraflex spectrometer equipped with a pulsed nitrogen laser $(337 \mathrm{~nm})$, in linear positive ion mode, using a $20-\mathrm{kV}$ acceleration voltage. Samples were prepared by mixing equal volumes of a saturated solution of the matrix (sinapinic acid) in $0.1 \%$ TFA (aq.) acetonitrile $(2: 1)$, and the protein solution. From this mixture, $0.5 \mu \mathrm{L}$ was spotted on to a simple slide and allowed to evaporate to dryness. Bovine trypsinogen was used for internal calibration.

\subsection{Amidolytic Activity and Kinetic Parameters}

Amidolytic activity was determined using PFLNA as substrate at $45^{\circ} \mathrm{C}$ by spectrophotometric measurement of absorbance at $410 \mathrm{~nm}$, according to Filippova et al. [23]. The reaction mixture contained $1.5 \mathrm{~mL}$ of $0.1 \mathrm{M}$ phosphate buffer $\mathrm{pH} 7.5$, containing $0.3 \mathrm{M} \mathrm{KCl}, 0.1 \mathrm{mM}$ EDTA and $3 \mathrm{mM}$ DTT, $180 \mu \mathrm{L}$ of substrate $(0.025-0.5 \mathrm{mM}$ final concentration) and $120 \mu \mathrm{L}$ of enzyme. An arbitrary enzyme activity unit ( $\mathrm{U}_{\text {PFLNA }}$ ) was defined as the amount of protease that released $1 \mu \mathrm{mol}$ of $p$-nitroaniline per min in the assay conditions. The kinetic parameters $\left(\mathrm{V}_{\mathrm{m}}, \mathrm{K}_{\mathrm{m}} \mathrm{y}\right.$ $\mathrm{K}_{\mathrm{cat}}$ ) of granulosain I were calculated using linear regression analysis by means of Lineweaver-Burke, Wolf-Hanes y Eadie-Hofstee plots.

\subsection{N-terminal Sequence}

The protein band in the SDS-PAGE of the purified protease, granulosain I, was transferred onto a PVDF membrane (Millipore) and washed several times with deionized water. The N-terminal sequence was determined by Edman's automated degradation using a Beckman LF3000 protein sequencer equipped with a System Gold (Beckman) PTHamino acid analyzer. Protein homology searches were performed using the Blast network service [24].

\section{Results}

\subsection{Purification of Crude Extract}

The crude extract used for the isolation of granulosain I was obtained from ripe fruits of S. granuloso-leprosum.

Previous studies carried out on this extract found it had significant proteolytic activity ( $8 \mathrm{Ucas} / \mathrm{mg}$ ) and determined the physicochemical parameters in which this enzymatic preparation showed maximum activity and stability [25].

The purification of proteases from the crude extract was achieved by a two-step procedure. The first step was the treatment of the crude extract with four volumes of cold acetone $\left(-20{ }^{\circ} \mathrm{C}\right)$ to eliminate soluble carbohydrates as well as phenolic compounds, which could oxidize and react irreversibly with the proteins present in the homogenate. The redissolved acetone precipitate (RAP) contained $89 \%$ of the proteins and $76 \%$ of the total caseinolytic activity present in the crude extract.

The second purification step was column chromatography of the RAP using a CM-Sepharose FF column in a FPLC system. The elution profile is shown in Fig. 1. The unbound eluate exhibited low activity toward casein, but the two fractions eluted after the application of the linear $\mathrm{NaCl}$ gradient it were both proteolytically active. The second peak (P II), which eluted at $0.25 \mathrm{M} \mathrm{NaCl}$, showed higher specific activity (10 Ucas/mg) and was therefore selected for further study.

\subsection{Biochemical Characterization of Granulosain I}

SDS-PAGE analysis of peak II fractions showed a single homogeneous protein band. Mass spectrometry confirmed the homogeneity of this protein, its molecular mass (Mr) was 24,746 Da (Figs. 2 and 3).

According to nomenclature recommendations for proteases [26], a protease of peak II was named Granulosain I.

Isoelectric focusing and specific revealed for proteases (zymogram) showed that granulosain I had a pI higher than 9.3 (Fig. 2).

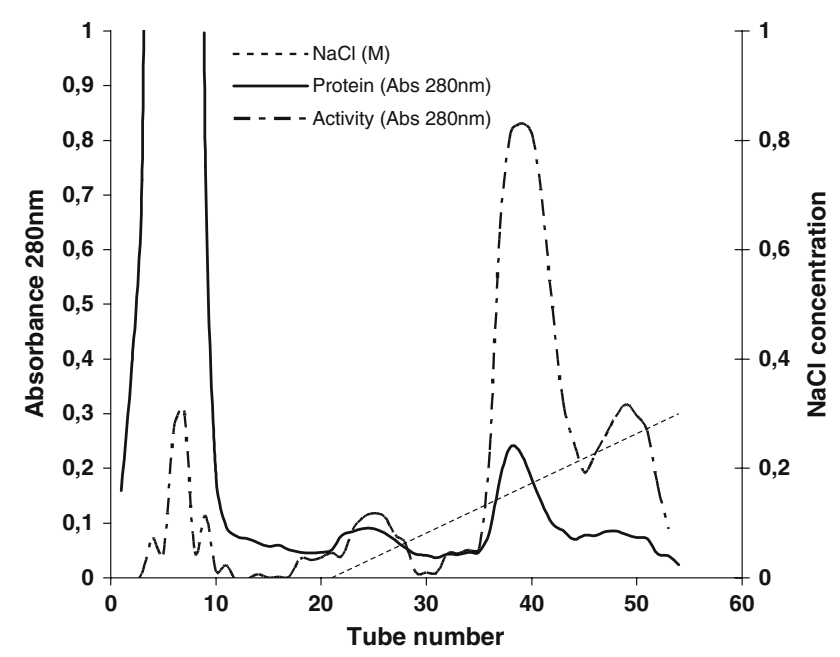

Fig. 1 Cation exchange chromatography (CM-sepharose fast flow, column Pharmacia Biotech XK 16) elution buffer: $50 \mathrm{mM}$ Tris- $\mathrm{HCl}$ (pH 7.5). Gradient: sodium chloride $0-0.3 \mathrm{M}$. Flow rate: $1 \mathrm{~mL} \mathrm{~min}^{-1}$. Fraction volume: $2.5 \mathrm{~mL}$ 

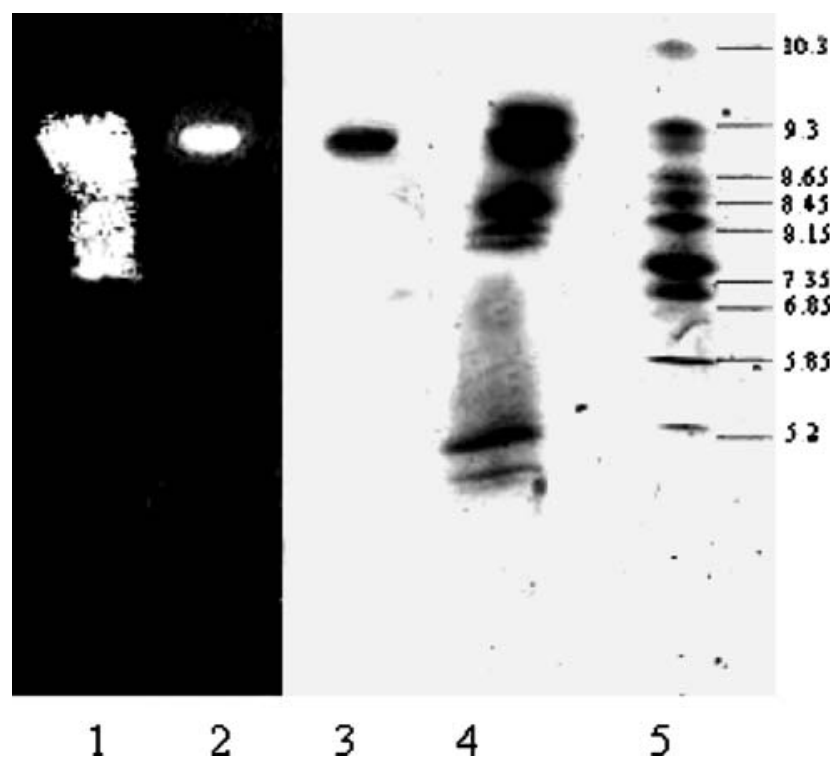

34

Fig. 2 Isoelectric focusing and zymogram of granulosain I and crude extract. Lane 1: zymogram of crude extract; Lane 2: zymogram of granulosain I; Lane 3: granulosain I; Lane 4: crude extract; Lane 5: isoelectric point markers

The $\mathrm{pH}$ range in which granulosain I showed high caseinolytic activity (greater than $90 \%$ ) was $7.0-8.6$ (Fig. 3).

The enzyme was completely inhibited by E-64 and iodoacetic acid. This behaviour is similar to that of the C1A family of cysteine proteases [12].

The effect of increasing concentrations of cysteine and 2-mercaptoethanol on granulosain I activity was studied. It was observed that both activators increased the activity in to a similar extent. In the case of cysteine the concentration that produced the greatest increment in activity (200\%) was $15 \mathrm{mM}$, while for 2-mercaptoethanol the concentration that produced the highest activation level $(200 \%)$ was $30 \mathrm{mM}$ (Fig. 4).

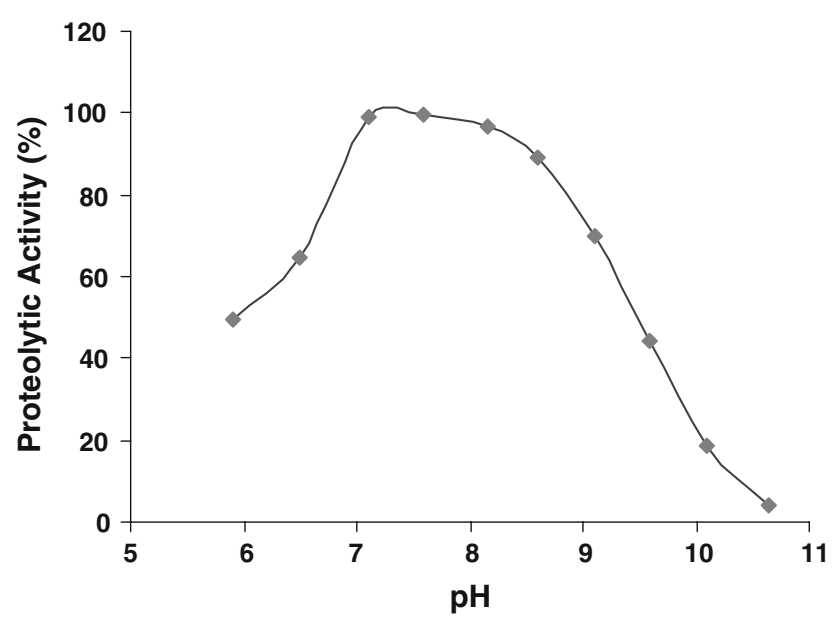

Fig. 3 Effect of $\mathrm{pH}$ on proteolytic activity of granulosain I, measured (pH range 6.0-10.6) using $50 \mathrm{mM}$ sodium salt of the following "Good" buffers: MES, MOPS, TAPS, AMPSO and CAPS

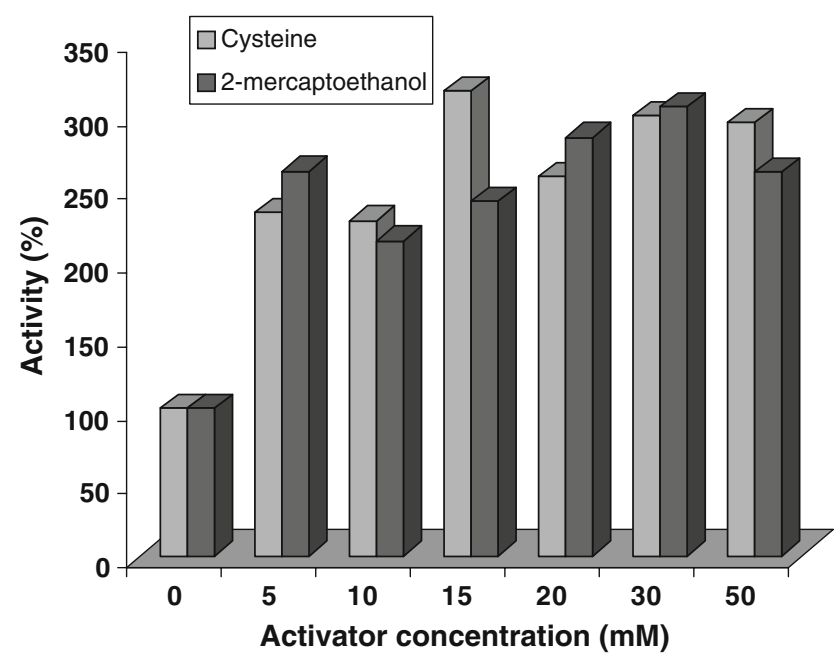

Fig. 4 Effect of activators on the proteolytic activity of granulosain I incubated different concentrations of each activator $30 \mathrm{~min}$ at $37^{\circ} \mathrm{C}$. Caseinolytic activity was measured $20 \mathrm{~min}$ at $37{ }^{\circ} \mathrm{C}$ using $0.1 \mathrm{M}$ Tris buffer $\mathrm{pH}: 7.5$

In active site titration with E-64, when activity was plotted against E-64 concentration, a straight line was obtained, which when extrapolated intersected the abscissa at $1.8 \mu \mathrm{M}$ E-64, corresponding to $45 \%$ of total enzyme (Fig. 5).

\subsection{Kinetic Parameters}

The amidolytic activity and the main kinetic parameters $(\mathrm{Km}, \mathrm{Vm}$, Kcat and $\mathrm{Kcat} / \mathrm{Km})$ of granulosain I were determined using PFLNA as substrate which has been extensively used to evaluate the activity of plant cysteine proteinases like papain, bromelain and ficin.

The values obtained for granulosain I was shown in Table 1.

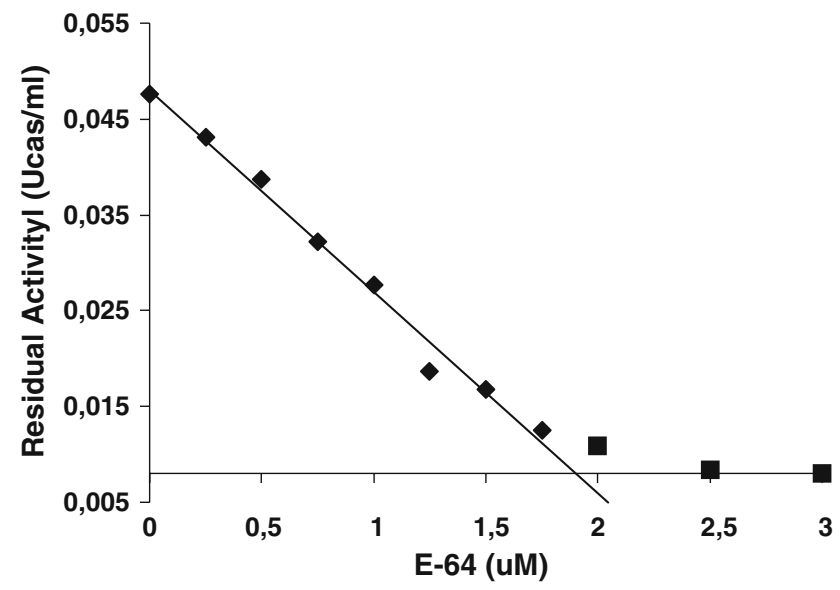

Fig. 5 Titration of active site of granulosain I with E-64. Granulosain I previously activated with $15 \mathrm{mM}$ of cysteine was preincubated for $30 \mathrm{~min}$ at $37{ }^{\circ} \mathrm{C}$ with different concentrations of E-64. Residual azocasein activity was measured in $0.1 \mathrm{M}$ Tris buffer $\mathrm{pH} 7.5$ 


\subsection{Sequence Analysis}

The N-terminal aminoacid sequence obtained for granulosain I (DRLPASVDWRGKGVLVLVKNQGQC) was compared with sequences of other plant proteases (Table 2).

\section{Discussion}

Supported in a marked interest by the available regional vegetable biodiversity, it is searched to obtain proteolytic catalysts that allow their application in different biotechnological processes, as well as the development of new undertaking.

Studies previously realized on ripe fruits extract of S. granuloso-leprosum (Solanaceae), demonstrated a significant and unusual proteolytic activity, for this vegetable family.

The Solanaceae family includes about 85 genera and 3000 species [43] but in spite of being an abundant and widely distributed family, to our knowledge there have been no reports of the isolation and biochemical and structural characterization of any proteolytic enzymes belonging to it. The majority of the existing reports come from physiological studies or gene expression from these enzymes under conditions of stress or pathogen attack [28, 44].

In this work we emphasized the functional, structural and enzymologic classification of the isolated protease.

Through simple two step procedure, was obtained a fraction with high specific activity and purity, proved by SDS-PAGE and MALDI-TOF/MS (Figs. 6 and 7) and named Granulosain I.

The molecular mass of Granulosain I obtained by mass spectrometry was $24,746 \mathrm{Da}$. This value is close to those reported for most of the plant cysteine proteinases of the C1A family, like papain $(23,800 \mathrm{Da})$, fruit bromelain $(25,000 \mathrm{Da})$, Ficinain $(25,000 \mathrm{Da})$ and chymopapain $(24,400 \mathrm{Da})$ [45].

Isoelectric focusing and zymogram demonstrated the basic characteristic of granulosain I (pI higher than 9.3, Fig. 2), in common with other plant peptidases. This is

Table 1 Kinetic parameters of granulosain I using PFLNA at different substrate concentrations

\begin{tabular}{lllll}
\hline & $\mathrm{K}_{\mathrm{m}}(\mathrm{mM})$ & $\mathrm{V}_{\max }(\mathrm{mM} / \mathrm{s})$ & $\mathrm{K}_{\mathrm{cat}}\left(\mathrm{s}^{-1}\right)$ & $\mathrm{K}_{\mathrm{cat}} / \mathrm{K}_{\mathrm{m}}\left(\mathrm{s}^{-1} \cdot \mathrm{M}^{-1}\right)$ \\
\hline L.B. & 0.6158 & 0.00037 & 9.79 & $15.90 \times 10^{3}$ \\
Hanes & 0.5621 & 0.00035 & 9.26 & $16.47 \times 10^{3}$ \\
Hofstee & 0.5633 & 0.00030 & 7.94 & $14.09 \times 10^{3}$ \\
\hline
\end{tabular}

The initial reaction rate was determined by monitoring the absorbance at $410 \mathrm{~nm}$ every $5 \mathrm{~s}$ for $2 \mathrm{~min}$ at $45^{\circ} \mathrm{C}$. LB: Lineweaver-Burke plot. Hanes: Hanes-Wolf plot. Hofstee: Eadie-Hofstee plot evidence that in the enzyme's native structure, the most external amino acids are basic.

The optimal $\mathrm{pH}$ range (7.0-8.6) is consistent with that of most cysteine proteases belonged to the papain family. In this $\mathrm{pH}$ range, these enzymes have a monoprotonated thiolimidazole bond (Cys-His) which is essential for catalytic activity [46]. It might therefore be inferred that granulosain I has a similar mechanism to the cysteine proteases of the C1A family.

The complete inhibition of proteolytic activity when granulosain I was preincubated with E-64 or Iodoacetamide proved that the enzyme's active site contains sulfhydryl residues that are essential for its catalytic activity.

E-64 has broad specificity and a fast reaction mechanism for papain family members. It is virtually ideal as an active-site titrant, because it has been found to react with the sulfhydryl groups of active site on an equimolecular basis [20].

In the titration assay, only the $45 \%$ of total enzyme was active.

Reduction of proteolytic activity during the purification steps could be related to denaturalization of protease structure or autolysis events.

A prior reversible inhibition with $\mathrm{HgCl}_{2}$ of enzyme prevents these events (Data not shown).

The activator effect of increasing concentrations of cysteine and 2-mercaptoethanol confirmed the cysteinic nature of the active site and the dependence of catalytic activity on sulfhydryl groups. It also demonstrated that the enzyme required reduced conditions for activity.

The specificity subsite predominant in most peptidases of subfamily $\mathrm{C} 1 \mathrm{~A}$ is $\mathrm{S} 2$, which commonly displays a preference for occupation by a bulky hydrophobic side chain, and not a charged one [1]. The amidolytic activity as well as the main kinetic parameters $(\mathrm{Km}, \mathrm{Vm}$, Kcat and $\mathrm{Kcat} / \mathrm{km}$ ) were determined using PFLNA as substrate (Table 1), which has been extensively used to evaluate the activity of plant cysteine proteinases like papain, bromelain and ficin. (Phenylalanine in P2 position which give thiol proteinases specificities).

The $\mathrm{Km}$ value obtained for granulosain I $(0.6 \mathrm{mM})$, showed a lower affinity for PFLNA than papain $(0.34 \mathrm{mM})$, bromelain $(0.30 \mathrm{mM})$ and ficin $(0.43 \mathrm{mM})$ [23].

It is probable that a different spatial disposition of the active site amino acids of granulosain I compared with the active sites of papain, bromelain and ficin, determines its differential affinity for the substrate.

The N-terminal sequence of granulosain I (DRLPASVDWRGKGVLVLVKNQGQC) showed two highly conserved regions (DWR and RNQG) present in most peptidases belonging to the C1A family. Though in 
Table 2 Comparision of the N-terminal amino acid sequences of granulosain I with other animal and plant cysteine proteases using the BLAST network service [24]

\begin{tabular}{|c|c|c|c|c|}
\hline Protease and/or source & $\mathrm{N}$-terminal sequence & $\begin{array}{l}\text { Identities } \\
(\%)\end{array}$ & $\begin{array}{l}\text { Positives } \\
(\%)\end{array}$ & References \\
\hline Granulosain I & DRLPASVDWRGKGVLVLVKNQGQC & $\begin{array}{l}24 / 24 \\
(100 \%)\end{array}$ & & \\
\hline Cathepsin L [Suberites domuncula] & $\begin{array}{l}\text { ASVDWR KGV+ VKNQGQC } \\
\text { ASVDWRQKGVVSEVKNQGQC }\end{array}$ & $\begin{array}{l}16 / 20 \\
(80 \%)\end{array}$ & $\begin{array}{l}17 / 20 \\
(85 \%)\end{array}$ & Muller et al. [27] \\
\hline $\begin{array}{l}\text { Cysteine protease [Solanum } \\
\text { tuberosum] }\end{array}$ & $\begin{array}{l}\text { D LP SVDWR KGVLV VK+QG C } \\
\text { DSLPESVDWRDKGVLVGVKDQGSC }\end{array}$ & $\begin{array}{l}18 / 24 \\
(75 \%)\end{array}$ & $\begin{array}{l}19 / 24 \\
(79 \%)\end{array}$ & Avrova et al. [28] \\
\hline Cysteine proteinase [Petunia $x$ hybrida] & $\begin{array}{l}\text { LP SVDWR KG + VKNQGQC } \\
\text { LPKSVDWRKKGAVTPVKNQGQC }\end{array}$ & $\begin{array}{l}16 / 22 \\
(72 \%)\end{array}$ & $\begin{array}{l}17 / 22 \\
(77 \%)\end{array}$ & Jones et al. [29] \\
\hline Cathepsin L [Homo sapiens] & $\begin{array}{l}\text { P SVDWR KG + VKNQGQC } \\
\text { PRSVDWREKGYVTPVKNQGQC }\end{array}$ & $\begin{array}{l}15 / 21 \\
(71 \%)\end{array}$ & $\begin{array}{l}16 / 21 \\
(76 \%)\end{array}$ & Urbich et al. [30] \\
\hline $\begin{array}{l}\text { Cathepsin L-like cys. proteinase } \\
\text { [Brugia malayi] }\end{array}$ & $\begin{array}{l}\text { +RLP+SVDWRK GVL V+NQG+C } \\
\text { ERLPSSVDWRKKGVLTPVRNQGEC }\end{array}$ & $\begin{array}{l}17 / 24 \\
(70 \%)\end{array}$ & $\begin{array}{l}21 / 24 \\
(87 \%)\end{array}$ & Guiliano et al. [31] \\
\hline $\begin{array}{l}\text { Low-temperature-induced cysteine } \\
\text { proteinase precursor }\end{array}$ & $\begin{array}{l}\text { D LP S+DWR KGVLV VK+QG C } \\
\text { DSLPESIDWREKGVLVGVKDQGSC }\end{array}$ & $\begin{array}{l}17 / 24 \\
(70 \%)\end{array}$ & $\begin{array}{l}19 / 24 \\
(79 \%)\end{array}$ & Schaffer et al. [32] \\
\hline CYP1 [Lycopersicon esculentum] & $\begin{array}{l}\text { D LP S+DWR KGVLV VK+QG C } \\
\text { DSLPESIDWREKGVLVGVKDQGSC }\end{array}$ & $\begin{array}{l}17 / 24 \\
(70 \%)\end{array}$ & $\begin{array}{l}19 / 24 \\
(79 \%)\end{array}$ & Lers et al. [33] \\
\hline Funastrain c II & $\begin{array}{l}\text { LP SVDWR KGVV +NQG+C } \\
\text { LPNSVDWRQKGVVSAIRNQGKC }\end{array}$ & $\begin{array}{l}15 / 22 \\
(68 \%)\end{array}$ & $\begin{array}{l}17 / 22 \\
(77 \%)\end{array}$ & Morcelle et al. [34] \\
\hline Asclepain $\mathrm{f}$ & $\begin{array}{l}\text { LP SVDWR KGVV +NQG+ } \\
\text { LPDSVDWREKGVVFPIRNQGK }\end{array}$ & $\begin{array}{l}14 / 21 \\
(67 \%)\end{array}$ & $\begin{array}{l}16 / 22 \\
(76 \%)\end{array}$ & Trejo et al. [35] \\
\hline Cysteine protease $[$ Oryza sativa $]$ & $\begin{array}{l}\text { D LPASVDWR KG + +K+QGQC } \\
\text { DALPASVDWRTKGAVTRIKDQGQC }\end{array}$ & $\begin{array}{l}16 / 24 \\
(66 \%)\end{array}$ & $\begin{array}{l}19 / 24 \\
(79 \%)\end{array}$ & $\begin{array}{l}\text { The Rice Chrom. } 11 \text { and } 12 \\
\text { Seq. Consortia [36] }\end{array}$ \\
\hline Cysteine proteinase [Glycine max] & $\begin{array}{l}\text { +PASVDWR KG + VK+QG C } \\
\text { VPASVDWRKKGAVTDVKDQGHC }\end{array}$ & $\begin{array}{l}14 / 22 \\
(63 \%)\end{array}$ & $\begin{array}{l}17 / 22 \\
(77 \%)\end{array}$ & Ling et al. [37] \\
\hline SAG12 [Arabidopsis thaliana $]$ & $\begin{array}{l}\text { LP SVDWR KG + +KNQG C } \\
\text { LPVSVDWRKKGAVTPIKNQGSC }\end{array}$ & $\begin{array}{l}14 / 22 \\
(63 \%)\end{array}$ & $\begin{array}{l}16 / 22 \\
(72 \%)\end{array}$ & Asamizu et al. [38] \\
\hline Chymopapain & $\begin{array}{l}\text { P S+DWR KG + VKNQG C } \\
\text { PQSIDWRAKGAVTPVKNQGAC }\end{array}$ & $\begin{array}{l}13 / 21 \\
(61 \%)\end{array}$ & $\begin{array}{l}15 / 21 \\
(71 \%)\end{array}$ & Taylor et al. [39] \\
\hline Philibertain g I & $\begin{array}{l}\text { LPASVDWR +G ++ +++QGQC L } \\
\text { LPASVDWRKEGAVLPIRHQGQC }\end{array}$ & $\begin{array}{l}13 / 22 \\
(59 \%)\end{array}$ & $\begin{array}{l}19 / 22 \\
(86 \%)\end{array}$ & Sequeiros et al. [40] \\
\hline Asclepain c I & $\begin{array}{l}\text { LP SVDWR KGV+QG+C } \\
\text { LPNSVDWRQKGVVFPIRDQGKC }\end{array}$ & $\begin{array}{l}13 / 22 \\
(59 \%)\end{array}$ & $\begin{array}{l}15 / 22 \\
(68 \%)\end{array}$ & Liggieri et al. [41] \\
\hline $\begin{array}{l}\text { Cysteine protease } \\
\quad[\text { Lycopersicon pennellii }]\end{array}$ & $\begin{array}{l}\mathrm{D}+\mathrm{P}+++\mathrm{DWR} \mathrm{G}+\mathrm{VKNQGQC} \\
\text { DDMPSNLDWRESGAVTQVKNQGQC }\end{array}$ & $\begin{array}{l}13 / 24 \\
(54 \%)\end{array}$ & $\begin{array}{l}18 / 24 \\
(75 \%)\end{array}$ & Kruger et al. [42] \\
\hline
\end{tabular}

granulosain I the RNQG region was changed to KNQG, this is a conservative change (both basic residues, Arg to Lys). Granulosain I exhibited a high degree of identity (greater than $70 \%$ ) with other plant cysteine proteases, especially with those found in the Solanaceae family (Solanum tuberosum, Lycopersicum esculentum) and with the mammalian cathepsins. These proteases share their general architecture as well as also the micro-arrangement of the catalytic triad (Cys 25, His 159 and Asn 175, according to papain numbering). The presence of a Gln residue in the 21 position is essential for catalytic activity as it helps the catalytic triad to form the "oxoanion hole".

Little is known about the physiological functions of these peptidase. In plants, for example, they have been associated with the mobilization of nutrients and defence against pathogens [3, 28, 47]. Many of these enzymes have important applications in medicine and biotechnology.

In conclusion, the biochemical characterization (MW, IEF, $\mathrm{pH}$ and inhibition studies) shows that granulosain I is a cysteine proteinase belonging to the CA1 family. The 


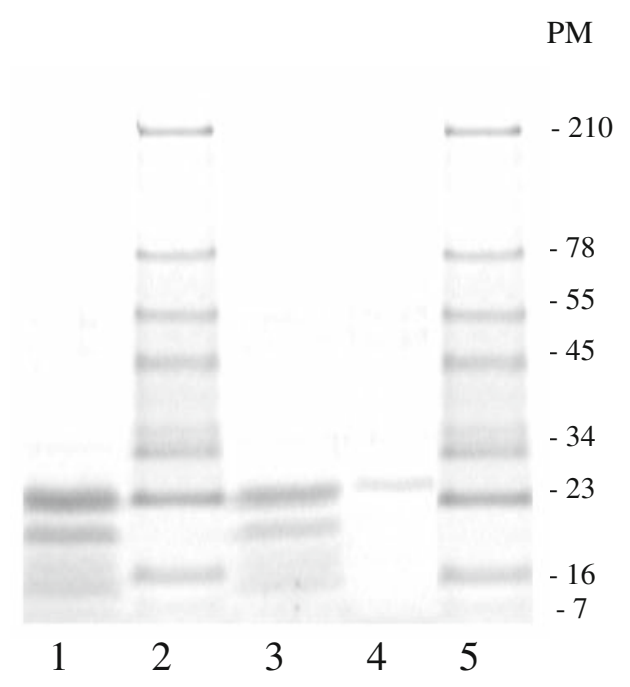

Fig. 6 SDS-PAGE on $12.5 \%$ polyacrylamide gel. $10 \mu \mathrm{g}$ of protein of crude extract and purified enzyme was loaded onto the gel. Lane 1: crude extract; lanes 2 and 5: MW standard markers: Myosin $(210 \mathrm{kDa})$, BSA $(78 \mathrm{kDa})$, glutamate dehydrogenase $(55 \mathrm{kDa})$, alcohol hydrogenase $(45 \mathrm{kDa})$, carbonic anhydrase $(34 \mathrm{kDa})$, myoglobin $(23 \mathrm{kDa})$, lysozyme (16 kDa), and aprotinin (7 kDa); Lane 3: redissolved acetone precipitate; Lane 4: granulosain I

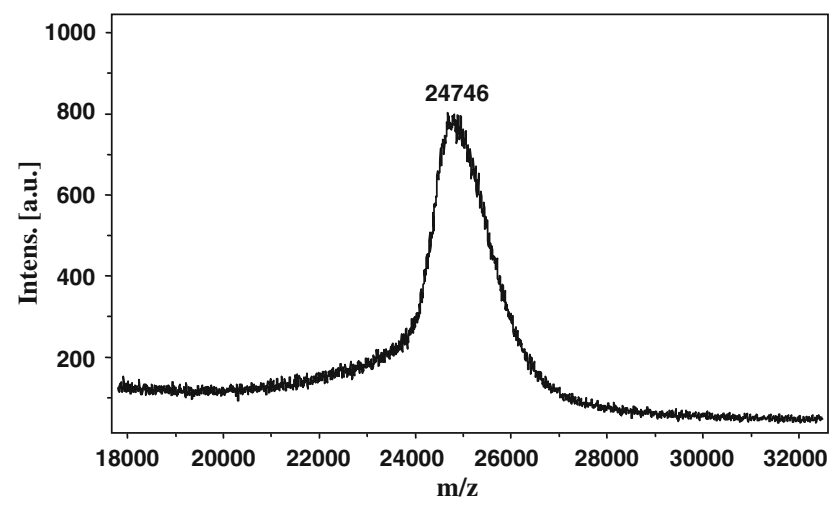

Fig. 7 Mass spectrometry of granulosain I. Sample was prepared by mixing equal volumes of protein solution and MS matrix solution ( sinapinic acid dissolved in $01 \%$ of trifluoroacetic acid)

kinetic studies as well as the $\mathrm{N}$-terminal sequence comparison gives granulosain I a differential identity within this family.

This studies defining optimum working conditions, stability to storage and temperature, size and electrophoretic characteristics will allow us to develop guidelines for the use of these enzymes in biotechnological processes.

Acknowledgments This work was supported by grants from CYTED (Project IV.22) and PEDECIBA (Chemistry area). Amino acid sequence and mass spectrometry determinations were done at the Institut de Biomedicina y Biotecnología, Universitat Autónoma de Barcelona, Spain. Dr. Valerie Dee undertook linguistic revision of this paper.
Open Access This article is distributed under the terms of the Creative Commons Attribution Noncommercial License which permits any noncommercial use, distribution, and reproduction in any medium, provided the original author(s) and source are credited.

\section{References}

1. Rawlings NM, Barrett AJ (2004) In: Barrett AJ, Rawlings NM, Woessner JF (eds) Handbook of proteolytic enzymes, 2nd edn., vol. II. Academic Press, London, pp 1051-1071

2. Wiederanders B (2003) Acta Biochimica Polonica 50:691-713

3. van der Hoorn RAL, Leeuwenburgh MA, Bogyo M, Joosten MHAJ, Peck SC (2004) Plant Physiol 135:1170-1178

4. Fischer J, Becker C, Hillmer S, Horstmann C, Neubohn B, Schlereth A, Senyuk V, Shutov A, Muntz K (2000) Plant Mol Biol 43:83-101

5. Ueda T, Seo S, Ohashi Y, Hashimoto J (2000) Plant Mol Biol 44:649-657

6. Schlereth A, Standhardt D, Mock HP, Muntz K (2001) Planta 212:718-727

7. Wisniewski K, Zagdanska B (2001). J Exp Bot 52:1455-1463

8. Furmonaviciene R, Sewell HF, Shakib F (2000) Clin Exp Allergy 30:1307-1313

9. Nettis E, Napoli G, Ferrannini A, Tursi A (2001) Allergy 56: $257-258$

10. Guadix A, Guadix EM, Páez-Dueñas MP, González-Tello P, Camacho F (2000) Ars Pharmaceutica 41:79-89

11. Uhlig H (1998) Industrial enzymes and their applications. Wiley, New York, pp 146-147

12. Vallés D, Furtado S, Villadóniga C, Cantera AMB (2004a) Int J Biotechnol 6:346-360

13. Vallés D, Furtado S, Cantera AMB (2007) Enzyme Microbial Technol 40:409-407

14. Bohs L, Olmstead RG (1997) Syst Bot 22:5-17

15. Scopes, RK (1994) In: Robert CG (ed) Protein purification: principles and practice, 3rd edn, vol. 96. Pringer-Verlag NY Inc, New York, pp 317-321

16. Bradford MB (1976) Anal Biochem 72:248-254

17. Bruno MA, Pardo MF, Caffini NO, López LMI (2003) J Protein Chem 22:127-134

18. Castro S, Vázquez D, Cantera AMB (1996) Int Dairy J 5:1-10

19. Good NE, Izawa S (1972) Meth Enzymol 24:53-68

20. Salvesen GS, Nagase, H (2001) Inhibition of proteolytic enzymes. In: Beynon R, Bond JS (eds) Proteolytic enzymes, 2nd edn. Oxford University Press, Oxford, pp 105-128

21. Westergaar JL, Hackbarth C, Treuhaft MW, Roberts RC (1980) J Immunol Meth 34:167-175

22. Laemmli UK (1970) Nature 227:680-685

23. Filippova IYu, Lysogorskaya EN, Oksenoit ES, Rudenskaya GN, Stepanov VM (1984) Anal Biochem 143:293-297

24. Altschul SF, Madden TL, Schaffer AA, Zhang J, Zhang Z, Miller W, Lipman DJ (1997) Nucleic Acids Res 25:3389-3342

25. Vallés D, Bruno MA, González M, López LMI, Cantera AMB, Caffini NO (2004b) Biocell 28:72

26. Barret AJ (2001) Proteolytic enzymes: nomenclature and classification. In: Beynon R, Bond JS (eds) Proteolytic enzymes, 2nd edn. Oxford University Press, Oxford (UK), pp 1-20

27. Muller WE, Krasko A, Le Pennec G, Schroder HC (2003) Microsc Res Tech 62:368-377

28. Avrova AO, Stewart HE, De Jong WD, Heilbronn J, Lyon GD, Birch PR (1999) Mol Plant Microbe Interact 12:1114-1119

29. Jones ML, Chaffin GS, Eason JR, Clark DG (2005) J Exp Bot $56: 2733-2744$ 
30. Urbich C, Heeschen C, Aicher A, Sasaki K, Bruhl T, Farhadi MR, Vajkoczy P, Hofmann WK, Peters C, Pennacchio LA, Abolmaali ND, Chavakis E, Reinheckel T, Zeiher AM, Dimmeler S (2005) Nat Med 11:206-213

31. Guiliano DB, Hong X, McKerrow JH, Blaxter ML, Oksov Y, Liu J, Ghedin E, Lustigman S (2004) Mol Biochem Parasitol 136:227-242

32. Schaffer MA, Fischer RL (1988) Plant Physiol 87:431-436

33. Lers A, Burd S, Sonego L, Khalchitski A, Lomaniec E (1998) Plant Physiol 116:1193

34. Morcelle del Valle SR, Trejo SA, Canals F, Avilés FX, Priolo NS (2004) Protein J 23:205-215

35. Trejo SA, López LMI, Cimino CV, Caffini NO, Natalucci CL (2001) J Protein Chem 20:445-453

36. The Rice Chromosomes 11 and 12 Sequencing Consortia (2005) BMC Biol 3:20

37. Ling JQ, Kojima T, Shiraiwa M, Takahara H (2003) Biochim Biophys Acta 1627:129-139

38. Asamizu E, Sato S, Kaneko T, Nakamura Y, Kotani H, Miyajima N, Tabata S (1998) DNA Res 5:379-391
39. Taylor MA, Al-Sheikh M, Revell DF, Sumner IG, Connerton IF (1999) Plant Sci 145:41-47

40. Sequeiros C, Torres MJ, Trejo SA, Esteves JL, Natalucci CL, Lopez LMI (2005) Protein J 24:445-453

41. Liggieri C, Arribére M, Trejo S, Canals F, Avilés F, Priolo N. (2004) Protein J 23:403-411

42. Kruger J, Thomas CM, Golstein C, Dixon MS, Smoker M, Tang S, Mulder L, Jones JD (2002) Science 296:744-747

43. Burkart A (1979) Dicotiledóneas metaclamídeas. In: Flora ilustrada de Entre Ríos Vol.6 parte V, Cientific colection of I.N.T.A, Buenos Aires, pp 346, 347, 358-360

44. Chen H-J, Huang D-J, Hou W-C, Liu J-S, Lin Y-H (2006) J Plant Physiol 163:863-876

45. Beers EP, Jones AM, Dickerman AW (2004) Phytochemistry 65:43-58

46. Polgár L (1973) Eur J Biochem 33:104-109

47. Grudkowska M, Zagdanska B (2004) Biochim Polonica 51: 609-624 